\title{
An Evaluation of Activity Books in Terms of Outcomes and Learning Processes Related to Food and Nutrition
}

\section{Etkinlik Kitaplarının Besin ve Beslenme ile İlgili Kazanımlar ve Öğrenme Süreçleri Açısından Değerlendirilmesi}

\author{
Gülşah İNALCIK * (iD) Duriye Esra ANGIN *
}

Received: 18 September 2020

Research Article

Accepted: 04 December 2020

ABSTRACT: This research was carried out to evaluate the activities in the Ministry of National Education Preschool Education Program Activity Book and Digital Education Platform Educational Information Network Teachers' Preschool Activity Book, in terms of outcomes, indicators and learning processes related to food and nutrition. In this research, document review method, which is one of the qualitative research methods, was utilized. The resources, on which the research will be carried out, were determined by one of the purposeful sampling methods; the criterion sampling method. The data were analyzed using descriptive analysis method. The documents discussed in the research have been scanned for learning outcomes related to food and nutrition and healthy nutrition with its indicators, nutrients, food groups, where food comes from, importance of eating various foods, benefits of foods. As a result of the research, it has been determined that there are no learning outcomes related to food and nutrition concepts in the activities and that no references have been made to food and nutrition concepts in learning processes in the Activity Book of Preschool Education Program. However, in the activities included in the Digital Education Platform Educational Information Network Teachers' Preschool Activity Book, not only learning outcomes related to food and nutrition were discussed, but also food and nutrition concepts were addressed in the learning processes. The results are presented in tables, and suggestions were made at the end of the paper.

Keywords: Preschool education program, activity book, learning outcomes and indicators, learning process, food and nutrition.

ÖZ: Bu araştırma Millî Eğitim Bakanlığı Okul Öncesi Eğitim Programı Etkinlik Kitabı ve Dijital Eğitim Platformu Eğitim Bilişim Ağı Öğretmenler için Okul Öncesi Etkinlik Kitabı içerisindeki etkinliklerin besin ve beslenme ile ilgili kazanım, gösterge ve öğrenme süreçleri açısından değerlendirilmesi amacıyla gerçekleştirilmiştir. Araştırmada nitel araştırma yöntemlerinden doküman incelemesi yöntemi kullanılmıştır. Araştırmanın yapılacağı kaynaklar amaçlı örnekleme yöntemlerinden ölçüt örnekleme yöntemi ile belirlenmiştir. Veriler betimsel analiz yöntemi kullanılarak analiz edilmiştir. Araştırmada ele alınan dokümanlar besin ve beslenme ile ilgili kazanımlar ve göstergeleriyle birlikte sağlıklı beslenme, besinler, besin grupları, besinlerin nereden geldiği, çeşitli besinlerden yemenin önemi, besinlerin faydaları kelimeleriyle de taranmıştır. Araştırmanın sonucunda, Okul Öncesi Eğitim Programı Etkinlik Kitabı'nda yer verilen etkinliklerde besin ve beslenme kavramları ile ilişkili kazanımların bulunmadığı aynı zamanda öğrenme süreçlerinde de besin ve beslenme kavramlarına yer verilmediği tespit edilmiştir. Dijital Eğitim Platformu Eğitim Bilişim Ağı Öğretmenler için Okul Öncesi Etkinlik Kitabı içerisinde yer verilen etkinliklerde ise, hem besin ve beslenme ile ilişkili kazanımların ele alındığı hem de öğrenme süreçlerinde besin ve beslenme kavramlarına yer verildiği bulunmuştur. Elde edilen bulgular tablolar halinde sunulmuş, araştırmanın sonunda konuyla ilgili önerilerde bulunulmuştur.

Anahtar kelimeler: Okul öncesi eğitim programı, etkinlik kitabı, kazanımlar ve göstergeleri, öğrenme süreci, besin ve beslenme.

\footnotetext{
* Graduate student, Aydın Adnan Menderes University, Aydin, Turkey, 1930803101@stu.adu.edu.tr, https://orcid.org/0000-0002-7457-3157

** Corresponding Author: Asst. Prof. Dr., Aydın Adnan Menderes University, Aydin, Turkey, esra.angin@ adu.edu.tr, https://orcid.org/0000-0001-6601-4892
}

\section{Citation Information}

İnalcık, G., \& Angın, D. E. (2021). An evaluation of activity books in terms of outcomes and learning processes related to food and nutrition. Kuramsal Eğitimbilim Dergisi [Journal of Theoretical Educational Science], 14(1), 3863. 
In order to continue living in a quality way, it is necessary to be physically, mentally and socially healthy and to know the factors affecting health well. Examining the factors affecting health, it is stated that the effect of nutrition is high; and considering reasons of diseases except for infections and accidents, the effect of factors except for nutrition is almost 10\% (Tayar, Korkmaz, \& Özkeleş, 2017). The World Health Organization [WHO] states that 38.3 million children under 60 months are overweight/obese, and this figure is almost 50 times (49.6) more among adults. Moreover, considering death reasons for children under 60 months, it was stated that $45 \%$ of these reasons are related to nutrition (WHO, 2020). Nutrition is an important concept in terms of its effects on individual's health as well as on society and country's economy. (Food and Agriculture Organization of the United Nations, 2005a; Türkiye Beslenme Rehberi [TÜBER], 2016).

Nutritional behaviour is a process that begins in the mother's womb and continues throughout our lives. It is necessary to be careful about the nutrition, beginning from the pregnancy period and to support the nutrition of the child according to the development and needs of the child in the postnatal period (Merdol, 2008). Considering that the habits acquired in the first years of life develop behaviours in later ages; it is stated that adequate and balanced nutrition and healthy eating habits should be acquired at an early age (T.C. Halk Sağlığı Genel Müdürlüğü, 2020b). For this reason, it is important to pay attention to the factors that affect nutritional behaviour. Nutritional behaviour of children; is affected by factors such as cultural factors, the number of family members, whether the family has received nutritional education or not, their attitudes during nutrition, their professions, their financial means and spendings on food, their meal planning, the child's age, food preferences and gender (Al-Hussein \& Kano, 2018; Hu et al., 2008; Köroğlu, 2009; Küçükkömürler, 2015; Merdol, 2008; Ünver, 2004). In cases where factors affecting nutritional behaviour are not taken into consideration, it can be said that these factors pave the way for inadequate and unbalanced nutrition and for the formation of nutritional problems.

We can notice nutritional problems in children; as a lack of appetite, choice of food, excessive food consumption, not following meals, not being able to eat/not eating alone and wrong food choices. Nutritional problems pave the way for extreme meagreness or obesity, vitamin deficiencies, tooth decay, constipation or diarrhea, blood pressure, diabetes, heart and infectious diseases; for situations such as fatigue, restlessness, irritability, attention deficit and learning difficulties (Food and Agriculture Organization of the United Nations, 2005a; Karaoğlu \& Samur, 2017; Marotz, 2012). In the Nutrition and Health Survey Turkey (T.C. Sağlık Bakanlığı, 2014), it is stated that children in our country, aged 0-60 months, have chronic diseases such as growth and development retardation, iron deficiency anemia and rickets. It is also stated that when children cannot be fed adequately in a balanced way in mother's womb and postnatal period their development and growth slow down and their mental development is negatively affected (Başkale, 2010; Merdol, 2008). Benton (2008) stated that when the cognitive development is undernourished in a critical period, its effects can be permanent. Considering the diseases and problems caused by nutrition, the importance of gaining the right nutritional habit in the early period is understood.

The preschool period is an important period for the formation of adequate and balanced nutritional habits (TÜBER, 2016). Confront healthy growth in a holistic sense 
and gaining sufficient and balanced nutritional habits for development, offering rich learning opportunities and possibilities as particularly important issues. Children start to acquire adequate and balanced nutrition habits in the family. It is important that parents are the right role models for children with their eating habits. It is necessary to sit at the table together, to pay attention not to deal with different situations during meals and not to differentiate between meals, to use positive statements about foods, to prefer healthy foods and taking care to have foods from each food group in meals (Karaoğlu \& Samur, 2017; Merdol, 2008; Okul Öncesi ve Okul Çağı Çocuklara Yönelik Beslenme Önerileri ve Menü Programları, 2013). When children start school; both the nutritional behaviour of teachers and being the right model for children and the offered activities as well are important (Carraway-Stage et al., 2014; Dazeley \& Houston-Price, 2015; Kabac1k \& Gül, 2016; Özcan, 2019). Considering that mealtimes are important while giving children the habit of sufficient and balanced nutrition, it is also stated that it's important for institutions and teachers to pay attention to sufficient time at mealtimes and to consume their meals with children (Healthy Eating Guidelines, 2004). However, the types and contents of activities offered to children through the curriculum also appear to us as an important title. As with all other titles, the Nutrition Education title is also included in the Preschool Education Curriculum in order to carry out a planned, high quality and inclusive education. In our country, it is desired to give children the importance of adequate and balanced nutrition via the Ministry of National Education (MoNE) Preschool Education Program (MEB, 2013a). And when we take a look at the Preschool Curricula in different countries; in the aims of the Hong Kong Preschool Education curriculum, it is stated that it should be supported that children acquire good habits and that they are healthy. And in line with this purpose, children are expected to gain self-care skills and to adopt a healthy lifestyle and continue in the following periods (Curriculum Development Council, 2017). In Romania's early childhood education curriculum, children in 0-3 age group are expected to know edible and nonedible food, and in 3-6 age group they are expected to apply some basic principles regarding having a healthy diet. It is seen that the theme "Who we are" in the curriculum includes our body, our own and family health (Curriculum Pentru Educatia Timpurie Romania, 2019). In the Swedish Preschool Curriculum, physical activity is also emphasized along with a healthy diet and lifestyle and the understanding of the importance of taking care of children's health is aimed (Skolverket, 2020). In the Korean Preschool Education Curriculum, developing correct eating habits, creating healthy living habits and preventing diseases are included under the title of Health (Proclamation of the Ministry of Education and Human Resources Development, 2007). An educational project called "Ackerheldenmachen Schule-Farm heroes go to school" has been carried out to inform children about health and nutrition in Germany and Australia since 2013. In the scope of this project, children and young people are given the opportunity to experience growing organic vegetables (Ackerhelden, 2020). In the USA, we can notice the MyPlate Curriculum developed by the Ministry of Agriculture to support Nutrition Education. Discover MyPlate offers a free access set for teachers in Preschool Nutrition Education. The set includes resources such as activity suggestions, teacher guide, curriculum, meal cards and mini books (USDA Food and Nutrition Service, 2020). Within the framework of Leonardo Da Vinci Project, Turkey, Germany, Austria, Latvia and Romania have developed a nutrition guide for early childhood 
active stakeholders. This guide mentions issues such as importance of nutrition, attitudes of pre-school teachers towards nutrition education, learning objectives and activity samples (Angın, Aktaş, \& Cebirbay, 2015).

Considering that education provides behavioural change in individuals; including concepts related to nutrition in the education process is important in terms of increasing the knowledge level of nutrition and gaining a healthy eating habit. When the studies on nutrition education are examined, the results of the nutrition education given to children show that; nutritional behaviours were positively affected, the consumption of healthy foods such as vegetables, fruits, milk and dairy products, adequate and balanced nutrition habits, the rate of regular meals, the level of nutritional knowledge and healthy snack choices have increased, the consumption of junk food and packaged food decreased (Alay, 2019; Başkale, 2010; Franciscato et al., 2019; Hu et al., 2008; Matvienko, 2007; Ünver, 2004). At the same time, when looking at the two studies done by Kerkez (2018) and Ocak, Duban, and Yağıcı (2016), it was concluded that children; know food but do not know whether they are healthy or not, have a lack of knowledge about adequate and balanced nutrition and define nutrition as "eating".

Nutrition education in early childhood period can be defined as pre-planned, theory-based and partners involved educational activities in which appropriate educational methods are employed to make desired changes in the behaviors of children with regard to foods, healthy nutrition and food choice. There are many factors for nutrition education, which aims to help children develop and sustain healthy nutrition behaviors, to be successful. The most important factors are the family, effective education programs and the teacher (Aktaş \& Angın, 2015).

As can be understood from the studies conducted, children have a lack of knowledge about the concept of nutrition. It is thought that in order to prevent this situation, nutrition education should be given to children and it should be supported by activities conducted in the classroom. While gaining healthy eating habits, it is important to provide nutritional training and activities appropriate to the age groups, developmental levels, individual differences, environmental conditions and culture of children. Activities; can include tales, books, dramas, case studies, culinary activities and can be given with an interdisciplinary approach (Karaoğlu \& Samur, 2017). It is also necessary to establish effective communication and cooperation between school and home in order to create nutritional behaviour changes in children (Marotz, 2012). When studies about nutrition in the preschool period are examined in general, it is seen that the effects of various nutrition education given to the family or the child (Aktaç, 2016; Aytekin, 2013; Obal1, 2009; Şenturan, 2017; Whiteley \& Matwiejczyk, 2015), the comparison of nutritional characteristics of children in different institutions (Akar, 2006; Kobak \& Pek, 2015), the factors affecting children's nutritional behaviour (AlHussein \& Kano, 2018; Köroğlu, 2009), nutritional habits (Oğuz, 2011) and perceptions (Uzakgiden, 2015), views, knowledge levels and practices on child nutrition of teachers and families (Liu et al., 2018; Tepe, 2010) are being investigated.

Considering that the education of children starts in the family and continues in schools, presenting concepts and contents of food and nutrition to children in applications in schools is thought to be important for children to positively affect their healthy food choices, increase their nutritional knowledge, gain healthy eating habits and acquire skills that they can apply throughout their lives. Behavioural changes desired to occur in children in preschool education institutions are offered to children through activities. The activities are prepared in line with the outcomes and indicators of 
the MoNE Preschool Education Program (PEP) (MEB, 2013a). Two books have been prepared by the MoNE in order to guide teachers while preparing activities. The first of these books which was prepared and published in 2013 with the PEP is named as "MoNE Preschool Education Program Activity Book (PEPAB) (MEB, 2013b)", the second book which was prepared in 2018 is called "MoNE Digital Education Platform Educational Information Network (DEPEIN) Preschool Activity Book for Teachers (PABFT)"'. When studies on activity books which are prepared for teachers of the PEP and preschool teachers are examined, it is seen that the studies contain program such as neurodevelopment (Aydın, Madi, Alpanda, \& Sazc1, 2012), development of musical skills (Kandır \& Türkoğlu, 2015), children's rights (Musaoğlu, 2012), health (Sönmez \& Seyhan, 2016), character education (Kocalar, 2019), examination in terms of 21stcentury skills (Tuğluk \& Özkan, 2019) and that the PEPAB studies contain such as examination in terms of phonological awareness (Kartal \& Güner, 2017). Looking at the studies that examine whether early childhood education programs include concepts related to food and nutrition or not; we can notice that the preschool curriculum in various provinces of Canada (Lynch, 2014) and Romania (Ilaş, 2015), the primary school curriculum in South Africa are evaluated with questionnaires (Nguyen, de Villiers, Fourie, Bourne, \& Hendricks, 2013) and we can notice studies which are examining the Australian New South Wales Primary Education Curriculum and teaching practices (de Vlieger, Riley, Miller, Collins, \& Bucher, 2018). Looking at the studies conducted in our country; we have reached the study carried out by Aktaş (2011) about concepts related to food and nutrition, ability, learning outcome, activity examples and sub-discipline acquisitions of the primary education 1-3grade Life Science curriculum. At the end of the study, it was found that there are concepts related to food and nutrition within three themes. It was also stated that food and nutritional gains and efficacy contents were included in the 1-3. grade Life Science curriculum should be renewed depending on the developments in food technology and nutrition science. At the same time, it has been determined that there hasn't been conducted any study which discusses food and nutritional outcomes and indicators of the (PEP). No research has been found on the PABFT (2018). The fact that the examination of the program in terms of containing the concepts of food and nutrition is not carried out at the basic education level and is not examined in the preschool period, which is a critical period in the formation of behaviours and knowledge, drew the attention to the gap in the literature and formed the basis for this research.

Considering all of this, based on the question "Are food and nutritional contents included in the learning processes of learning outcome, indicators and activities related to food and nutrition in the activities of the PEPAB (MEB, 2013b) and the PABFT (2018)?", the answers of the following questions have been sought in this study:

1. Are there any learning outcomes and indicators related to food and nutrition in the activities of the PEPAB (MEB, 2013b) and the PABFT (2018)?

2. What are the food and nutrition-related themes in the learning process of the activities including the learning outcome and indicators about food and nutrition in the PEPAB (MEB, 2013b) and the PABFT (2018)?

3. What are the food and nutrition-related themes in the learning process of the activities which are not including the learning outcome and indicators about food and nutrition in the PEPAB (MEB, 2013b) and the PABFT (2018)? 


\section{Method}

\section{Research Model}

The document analysis method, which is one of the qualitative research methods, was used in this research, which is aimed to examine the status of the concepts related to food and nutrition in the activities included in the PEPAB (MEB, 2013b) and the PABFT (2018). The document review method includes the analysis of written or visual materials such as films, videos, and photographs that contain information about the subject under investigation (Yıldırım \& Şimşek, 2016). In the research, a document review was carried out in order to examine the outcomes and indicators included in the program and activity books, which are written resources, and the concepts of food and nutrition in the activities.

\section{Working Group}

The PEPAB (MEB, 2013b) and the PABFT (2018) form the working group of the study in order to examine the outcomes, the indicators and the learning processes related to food and nutrition. While creating the working group, it was determined as a criterion to examine the content offered to teachers by the MoNE and therefore, the criterion sampling method, one of the purposeful sampling types, was used.

The PEPAB (MEB, 2013b). The PEPAB was prepared within the scope of the "Preschool Education Strengthening Project" and was published in 2013. In the introduction part of the book, the tag of the activities including the name of the activity, the type of activity, age group and adaptation are given. There are a total of 40 activities for children in different month groups and consists of 94 pages. The activities created according to the outcomes, the indicators and the concepts in the PEP (MEB, 2013a) have been prepared to support teachers while creating their own activities. It was expressed that teachers should create their own activity pool and prepare their activities in advance by making use of this published activity book to support the development of children according to their needs. It is thought that the book will guide teachers to generate various ideas and enrich their activities.

The PABFT (2018). The PABFT was prepared and published in 2018 in order to guide and support teachers due to the importance of creating an activity pool, the feedbacks from institutions and the increase in ready-made plans that are not suitable for children (Eğitim Bilişim A $\breve{g ̆}_{1}, 2020 \mathrm{a}$ ). In the contents section of the book, the name of the activity, the content of the activity, its type, outcomes and indicators and page number are specified. The activities were not prepared for different age groups, and the age group was not specified. There are 341 activities in the book and it consists of 378 pages. The fact that the activities are planned as integrated activities in accordance with the basic principles of the PEP, that certain days and weeks are included, that activities that can be applied in different regions are included, that there has been paid attention to the equality in the distribution of the activity types and that it is child-centred are among the features of the book (Eğitim Bilişim Ağ1, 2020b). 


\section{Data Collection}

In line with the general purpose of the research, firstly the activity books, which are published by the MoNE and which are providing the basis for preschool teachers to prepare their activities, have been determined and the outcomes and indicators related to food and nutrition in the PEP (MEB, 2013a) have been confirmed. In the second stage, the status of food and nutrition-related outcomes and indicators in the activities of both PEPAB (MEB, 2013b) and PABFT (2018) was examined. In the third stage, the food and nutritional content of the learning process of the activities within PEPAB (MEB, 2013b) and PABFT (2018) in which the outcomes and indicators related to food and nutrition are included, were examined. In the fourth stage the food and nutritional contents of the learning processes in the activities within PEPAB (MEB, 2013b) and PABFT (2018) in which the outcomes and indicators related to food and nutrition were not represented in the activities, were examined.

\section{Data Analysis}

In the research, the data were analysed with the descriptive analysis method. Descriptive analysis is the summarization and interpretation of data according to predetermined titles. This analysis method has four stages: creating a theme and processing the data accordingly, obtaining and interpreting the findings (Yıldırım \& Şimşek, 2016).

The outcomes and the indicators related to food and nutrition were scanned in the activities within PEPAB (MEB, 2013b) and PABFT (2018). In order to determine food and nutritional content in learning processes, scanning has been performed again using the words healthy nutrition, adequate and balanced nutrition, the importance of nutrition, vegetables, fruits, food groups and foods, how the food is obtained (where it comes from and how it is grown), the importance of eating various foods. The scanning process was carried out twice by the researcher in order to avoid an overlooked concept. At the same time, the activities were scanned by two experts working in the field of Preschool Education using the same keywords. All activities in the activity book have been transferred to a table. The activities determined in the keywords were marked in which activity they took place.

\section{Validity and Reliability}

The methods of ensuring validity and reliability in qualitative researches are quite different from quantitative researches. Erlandson et al. (1993) stated that the concept of internal validity is used as credibility, the concept of external validity as transmissibility and the concept of external reliability as confirmatory (As cited in Y1ldırım \& Şimşek, 2016). After the analysis conducted by the researcher to ensure credibility, the documents were also evaluated by two different researchers who are experts in the field of preschool education. It has been seen that the analysis of the expert and the analysis made by the researcher are consistent with each other. It is stated that detailed description and the sampling method are important in qualitative research to obtain transmissibility (Başkale, 2016). In the research, the detailed presentation of the findings and the research process and the fact that the sampling method is one of the purposeful sampling methods, increase the transmissibility. For verifiability, the data obtained in the research are stored so that another expert can also review it. 


\section{Ethical Statement}

There is no ethics committee report for the research, as the data in the research is obtained from the documents. However, during the research the reporting was carried out objectively and findings were presented clearly without alteration. In the process of the data analyze, the necessary sensitivity was shown. Activity books determined for analysis and other sources were definitely referenced.

\section{Findings}

The behaviours expected to be acquired by children about food and nutrition in the PEP (MEB, 2013a); are expressed as adequate and balanced nutrition, eating and drinking food and drinks in sufficient quantities, eating at mealtimes, avoiding food and drinks that negatively affect health, being healthy and paying attention to good manners while eating food and using appropriate tools and equipment during nutrition. In Table 1 , Outcomes and indicators regarding food and nutrition in the field of self-care skills in the PEP (MEB, 2013a) are given.

Table 1

Outcomes and Indicators Regarding Food and Nutrition Specified in the PEP (MEB, 2013a)

Self-Care Skills

Outcome 4: Has adequate and balanced nutrition. (Indicators: Eats/drinks enough food and drink. Makes an effort to eat at mealtimes. Avoids eating/drinking foods and drinks that negatively affect health. Pays attention to health and manners while eating food.)

Outcome 6: Uses the necessary tools and equipment for the daily life skills. (Indicators: Uses appropriate tools and equipment during nutrition.)

Outcome 8: Takes measures regarding health. (Indicators: Tells what to do to protect health. Describes the consequences that can occur when not paying attention to health. Does what it takes to protect health.)

When the outcomes and indicators in the PEP (MEB, 2013a) are examined, it is seen that three outcomes and eight indicators related to food and nutrition are under the title of self-care skills. The self-care skills outcome 4 includes "Has adequate and balanced nutrition" and the indicators "Eats/drinks enough food and drink", "Makes an effort to eat at mealtimes", "Avoids eating/drinking foods and drinks that negatively affect health", and "Pays attention to health and manners while eating food". Outcome 6 , includes "Uses the necessary tools and materials for the daily life skills", although there are three indicators under this outcome, only the indicator "Uses appropriate tools and equipment during nutrition" has been noticed to be related to food and nutrition. Outcome 8 includes "Takes measures regarding health" and the indicators "Tells what to do to protect health", "Describes the consequences that can occur when is not paying attention to health", and "Does what it takes to protect health" but there is no clear statement about food and nutrition. In the study outcome 8, were also examined, considering the need to pay attention to factors such as sufficient and balanced nutrition of the individual to protect our health, being aware of the importance of nutrition and sleep patterns. 
PEPAB (MEB, 2013b) and PABFT (2018): Investigation of the Status of Outcomes and Indicators Related to Food and Nutrition in Activities

There are 40 activities in the PEPAB (MEB, 2013b) and 341 activities in the PABFT (2018). Among the activities in PEBAP, it was determined that none of the outcomes and indicators (Outcome 4, 6, 8) related to food and nutrition discussed in the field of self-care skills in Table 1 were not included. Also, it was determined that the outcomes and indicators (Outcome 4, 6, 8) related to food and nutrition presented in the field of self-care skills took place in 15 activities in the PABFT and these activities are shown in Table 2.

Table 2

Outcomes and Indicators Related to Food and Nutrition Addressed in the Field of SelfCare Skills in the Activities of the PABFT (2018)

\begin{tabular}{ll}
\hline Activity Name & \multicolumn{1}{c}{ Outcomes and Indicators Taking Place } \\
\hline I am Eating Balanced, Thank You & $\begin{array}{l}\text { Outcome 4: Has adequate and balanced nutrition. (Indicators: } \\
\text { Eats/drinks enough food and drink. Makes an effort to eat at } \\
\text { mealtimes.) }\end{array}$ \\
& Outcome 4: Has adequate and balanced nutrition. (Indicators: \\
& Avoids eating/drinking foods and drinks that negatively affect \\
Fruit Salad & Oulth.) \\
& Outcome 6: Uses the necessary tools and materials for the daily \\
& life skills. (Indicators: Uses appropriate tools and equipment \\
& during nutrition.)
\end{tabular}

Five Soup

The Speed of My Heart

Let's Squeeze an Orange

Dental Health

I Brush My Teeth

I Wash My Hands, I Protect My Health

Wheel Games
Outcome 4: Has adequate and balanced nutrition. (Indicators: Eats/drinks enough food and drink. Makes an effort to eat at mealtimes. Pays attention to health and manners while eating food.)

Outcome 6: Uses the necessary tools and materials for the daily life skills. (Indicators: Uses appropriate tools and equipment during nutrition.)

Outcome 4: Has adequate and balanced nutrition. (Indicators: Avoids eating/drinking foods and drinks that negatively affect health.)

Outcome 4: Has adequate and balanced nutrition. (Indicators: Avoids eating/drinking foods and drinks that negatively affect health.)

Outcome 8: Takes measures regarding health. (Indicators: Tells what to do to protect health. Describes the consequences that can occur when is not paying attention to health.)

Outcome 8: Takes measures regarding health. (Indicators: Tells what to do to protect health. Describes the consequences that can occur when is not paying attention to health.)

Outcome 8: Takes measures regarding health. (Indicators: Tells what to do to protect health. Describes the consequences that can occur when is not paying attention to health.)

Outcome 8: Takes measures regarding health. (Indicators: Tells what to do to protect health. Describes the consequences that 
can occur when is not paying attention to health. Does what it takes to protect health.)

Ferment Your Own Yogurt

Food Plate

I Count while I'm Brushing

Is it Fresh or is it Stale?

Let's Design Our Own Scarf

Time to Move
Outcome 8: Takes measures regarding health. (Indicators: Does what it takes to protect health.)

Outcome 8: Takes measures regarding health. (Indicators: Tells what to do to protect health. Describes the consequences that can occur when is not paying attention to health. Does what it takes to protect health.)

Outcome 8: Takes measures regarding health. (Indicators: Tells what to do to protect health. Describes the consequences that can occur when is not paying attention to health.)

Outcome 8: Takes measures regarding health. (Indicators: Tells what to do to protect health.)

Outcome 8: Takes measures regarding health. (Indicators: Tells what to do to protect health. Describes the consequences that can occur when is not paying attention to health.)

Outcome 8: Takes measures regarding health. (Indicators: Tells what to do to protect health.)

The outcomes and indicators related to food and nutrition within the PABFT (2018) are included in the activities shown in Table 2. We can notice that the indicators "Eats/drinks enough food and drinks.", "Makes an effort to eat at mealtimes.", and "Pays attention to health and manners while eating food." which are belonging to this outcome, are taking place in the "Five Soup" activity. We can see that the "Avoids eating/drinking foods and drinks that negatively affect health." indicator is handled as the only indicator for this outcome in the "Fruit Salad", "The Speed of My Heart", and "Let's Squeeze an Orange" activities. The indicator "Uses appropriate tools and equipment during nutrition." of the "Uses the necessary tools and materials for the daily life skills." outcome is taking place in the "Fruit Salad" and "Five Soup" activities. The "Takes measures regarding health." outcome is taking place in the "Dental Health", "I Brush My Teeth", "I Wash My Hands, I Protect My Health", "Wheel Games”, "I Count While I am Brushing", "Let's Design Our Own Scarf”, "Ferment Your Own Yogurt", "Food Plate", "Is It Fresh or is it Stale?", and "Time to Move" activities. It is seen that all indicators of this outcome are represented only in the "Wheel Games" and "Food Plate" activities. The "Tells what to do to protect health." and "Describes the consequences that can occur when is not paying attention to health." indicators are included in the "Dental Health", "I Brush My Teeth", "I Wash My Hands, I Protect My Health", "I Count While I am Brushing", and "Let's Design Our Own Scarf" activities. In addition, there are three activities in which the only one of the indicators "Tells what to do to protect health." and "Describes the consequences that can occur when is not paying attention to health." belonging to this outcome is represented. These are the "Is it Fresh or is it Stale?" and "Time to Move" activities which are representing the "Tells what to do to protect health." indicator; and the "Ferment Your Own Yogurt" activity which is representing the "Does what it takes to protect health." indicator. 
Investigation of the Learning Process of the Activities that Represent the Outcomes and Indicators Concerning Food and Nutrition in the Field of Self-Care Skills in the PEPAB (MEB, 2013b) and PABFT (2018)

Due to the absence of food and nutrition-related outcomes and indicators (Outcome 4, 6, 8) in the field of self-care skills in the PEPAB (MEB, 2013b), it could not be examined in line with this sub-objective.

When the learning processes of the activities in the PABFT (2018) have been examined, it was determined that there was no food and nutritional content in seven activities. In the learning process of activities named "Dental Health", "I Brush My Teeth", "I Wash My Hands, I Protect My Health", "Wheel Games", "I Count While I am Brushing", "Let's Design Our Own Scarf", and "Time to Move" including the "Takes measures regarding health." outcome, the concepts related to food and nutrition are not included. During the learning processes of these activities, the importance of brushing teeth, washing hands, dressing according to the weather conditions and doing sports for our health are explained. In the PABFT (2018), it has been observed that the learning process of eight activities, which include the outcomes and indicators related to food and nutrition, which are discussed in the field of self-care skills, have food and nutritional content. The activities are listed in Table 3.

Table 3

PABFT (2018)

Activity Name

I am Eating Balanced, Thank You

Fruit Salad

Five Soup

The Speed of My Heart

Let's Squeeze an Orange

Ferment Your Own Yogurt

Food Plate

Is it Fresh or is it Stale?

Food and nutrition-related concepts are included in the "I am Eating Balanced, Thank You", "Fruit Salad", "Five Soup", "Speed of My Heart", "Let's Squeeze Orange", "Ferment Your Own Yogurt", "Food Plate", and "Is it Fresh or is it Stale?" activities in the outcome indicators and during the learning processes of activities in the PABFT (2018). In the learning processes of the activities in general; the importance of adequate and balanced nutrition, of consumption of some animal foods and fresh foods for our health, of beneficial and harmful foods, of mealtimes and what should be eaten at meals, of fruits and vegetables and what is happening; the examination of the texture, taste, smell and colour of various foods; their place in our culture; eating rules and food preparation processes are included. 
During the learning processes of the activities "Five Soup", "Fruit Salad", "Let's Squeeze Orange", and "Ferment Your Own Yogurt", various foods are prepared with the children. They prepare soups, salads, orange juice and yogurt themselves and talk about the tastes and benefits of foods. It is observed that the activities of "Five Soup", "Fruit Salad", "Let's Squeeze an Orange" activities are encouraged for children to consume fruits and vegetables during their learning process. The importance of fruits and vegetables and their benefits for our health take place in the learning process of these activities and children learn the properties of fruits and vegetables by using their sense organs. The benefits of yogurt and its place in our culture are mentioned in the activity "Ferment Your Own Yogurt" and the importance of fresh eggs for our health and the importance of eggs in healthy nutrition are mentioned in the activity "Is it Fresh or is it Stale?". In the "Let's Squeeze Orange" activity, it is emphasized that ready-made fruit juices are not healthy and that we should consume freshly squeezed fruit juices. In the same way, the harm of junk food and fizzy drinks for our health is explained in the "Food Plate" activity. In the "Is it Fresh or is it Stale?" activity, we can notice what we need to eat for a healthy diet, in the "Food Plate" activity, we can see the food groups to be consumed during the day and in the "The Speed of My Heart" activity, we can see the foods we need to consume for the healthy functioning of our internal organs. It is seen that the eating rules, what to do before and after eating are included in the activities "I Eat Balanced, Thank You" and "Five Soup" and in the "Food Plate" activity, we can notice that the mealtimes are included.

The importance of adequate and balanced nutrition and healthy eating is emphasized in all activities. In the learning processes of the "I am Eating Balanced, Thank You", "Fruit Salad", and "Food Plate" activities, it is seen that the importance of a balanced diet for us to maintain a healthy life and to continue our lives is expressed more clearly than other activities.

Investigation of the Concepts Related to Food and Nutrition in the Learning Process of the Activities in which the Outcomes and Indicators Related to Food and Nutrition Are Not Represented in the Field of Self-Care Skills in the Activities of the PEPAB (MEB, 2013b) and the PABFT (2018).

Among the 40 activities in the PEPAB (MEB, 2013b), it was determined that the name of the food is only mentioned in the "Journey of Milk Bottles" activity, but when the learning process of the activity was examined, it was confirmed that recycling was explained and that concepts and content related to food and nutrition were not included.

It is seen that a total of 15 activities which are "I Know Ashoura", "Brother Lemon", "We are Making Pickles", "Where Does Wheat Grow?", "I Eat Colourfully", "Winter Fruit", "We are Making Cookies", "We are Making Cake", "Sweet oh so Sweet!", "Lemon Vase", "Time to Discover Tastes", "Is it a Wish or a Need?", "Salt Lake", "Taste Jar", and "Lemon Vase", give place to concepts related to food and nutrition in the learning process.

In the activity named "I Know Ashoura", the names, tastes and benefits of the foods used in making Ashoura are discussed. The stages of making Ashoura are explained through a game and the place of Ashoura in our culture is mentioned. In the activity named "Brother Lemon", lemonade is made by expressing the benefits of lemon as it contains vitamin $\mathrm{C}$ and cleans the microbes in our body, and the fruits orange and 
tangerine are also included during the game. In the activity "We Are Making Pickles", the foods used in pickles are introduced and information is given about where, how and when they are grown. Children are given the opportunity to prepare pickles. In addition, talking about vegetables that should be consumed in autumn and taste experiments with vegetables are performed. In the activity "Where Is Wheat Grown?", in which region and how the wheat is grown, how pasta and bread is made by turning it into flour is explained. It is seen that the concept of healthy nutrition is included in the activity called "I eat colourfully". Children are shown photographs of fruits and vegetables, and they are given the opportunity to describe and ask the names of fruits and vegetables they don't know. In the "Winter Fruit" activity, a fruit cake is made with the children, names of various fruits are expressed. In the "We Are Making Cookies" activity, foods used in making cookies are introduced to the children and cookies are made together. In the activity called "We Are Making Cake", cake making is told by a story. As can be seen in the "We are Making Cookies" and "We Are Making Cake" activities, children learn the process of making a cookie and a cake and get to know the foods that are used, better. In the "Sweet oh so Sweet!" activity, the colour, shape, texture, smell, taste and what can be done with orange are discussed and orange jam is made together with the children. In the learning process of the "Salt Lake" activity, children are asked to separate various foods (such as raisins, salted peanuts, dried apricots, popcorn) as sweet and salty. In addition, it is emphasized where salt comes from, how it is obtained and how important natural resources are.

When the learning processes of the activities were examined, it was seen that the concepts of food and nutrition, the importance of healthy food and nutrition were expressed loud and clearly in the learning processes of some activities, while some of them included the concepts of food and nutrition was not so clear. In the activity "Is it a Wish or is it a Need?", it is discussed what products are needed to live a healthy life and the example, that a cake will be food we would like to buy even if we don't need it, is given in the learning process. In the "Lemon Vase" activity, children are shown a vase filled with lemons in order to create a still life work. During the learning process of the activity, there is a conversation about the colour, taste and amount of lemon. Salt, sugar, lemon, chili pepper, banana, Turkish bagel and pepper are included in the learning process of the "Time to Discover Tastes" activity. It is emphasized that the foods are grouped as sweet, salty and sour, and the flavours are taught with experiments and games. And in the "Taste Jar" activity, there is a conversation about sweet, salty, sour and bitter foods, and children are asked to separate the food they bring according to their taste. Having the activity names related to food and nutrition and looking at the learning processes, we can notice that there are also activities that are determined to not include food and nutrition. In the activity "I Found Bread but There Is Nothing to Eat with It", the word bread is used in the rhyme, but no message is given about food or nutrition during the learning process. In the name of the activity "The Sparrow's Dining House", the word food is mentioned, but when the learning process is examined, it is understood that its content is to prevent waste and to utilize leftover food. We can see the word egg in the name of the activity "Don't Let Your Egg Break" activity, but when the learning process is examined, it is seen that, in order to give responsibility to the children, it is ensured that they were able to bring the egg to the school without breaking it for a week. 


\section{Discussion}

In this part, findings obtained from the research are presented in the light of the literature.

Regarding the first sub-objective of the study, the status of including the outcomes and indicators (Outcome 4, 6, 8) related to food and nutrition determined under the title of self-care skills in the activities within PEPAB (MEB, 2013b) and PABFT (2018) was examined. In this context, it was determined that the activities in PEPAB (MEB, 2013b) did not include the outcomes and indicators (Outcomes 4, 6, and 8) under the title of self-care skills. It is stated that it is important to lay the foundations of healthy eating habits in this period, as personality and habits begin to be acquired in the preschool period. In addition, it is also necessary to offer and prefer healthy foods during this period, as the growth and development rates are quite high (T.C. Halk Sağlığg Genel Müdürlüğü, 2020b). When the literature is examined, researches and findings reveal how important the subject is. In the Nutrition and Health Survey of Turkey, which was conducted in 2010, the weight status of 2607 children between 0-60 months was examined; it was determined that $4.1 \%$ were very weak, $13.0 \%$ were weak, $14.6 \%$ were overweighed and $5.9 \%$ were obese (TBSA, 2014). It is stated that besides the psychological and physical health problems caused by nutrition, the nutritional status of the people also affects the economy and development of a country, it is indicated that education supporting healthy eating habits and healthy food choices in schools should be given to prevent the occurrence of the specified problems (T.C. Halk Sağlığ1 Genel Müdürlüğü, 2020b; The Nutrition Education Resource Guide for California Public Schools, 2017; Türkiye Sağlıklı Beslenme ve Hareketli Hayat Program1, 2019). In the academic year of 2018-2019, 2740 kindergartens, 148229 children, 7899 teachers, as well as parents and school staff, were trained in order to achieve the habit of healthy nutrition and regular physical activity on the basis of Healthy Nutrition and Active Life Program of Turkey with the title "Growing Turkey with Healthy Fed Active Students” (T.C. Halk Sağlı̆̆ı Genel Müdürlüğ̈̈, 2020a). In this direction, it can be said that activities that will support the outcome of healthy eating habits should be offered to children.

Various recommendations have been made by the Food and Agriculture Organization of the United Nations (FAO, 2005a), emphasizing the importance of nutrition education in schools in gaining healthy eating habits. In these suggestions; various projects, excursions, activities, regulation of school policies and Nutrition Education Curriculum, training for teachers, provision of material support to schools take place. Considering the explanations about the necessity of including Nutrition Education in schools, the importance of providing the resources that teachers will benefit from the Nutrition Education process is understood. In a study conducted to determine the problems experienced in Pre-School Education, most of the teachers stated that they could gain all the competencies, but some of them stated that they were not sufficient in gaining self-care skills (Yalçın \& Yalçın, 2018). This situation makes think about the necessity that self-care skills outcome and indicators should be included in the activities within PEPAB (MEB, 2013b), which are offered as a guide to teachers in providing children with self-care skills and healthy eating habits. Looking at the activities in the PABFT (2018), 15 activities were identified that include the outcomes and indicators (Outcomes 4, 6, and 8) related to food and nutrition. The outcomes in the 
determined activities; "Outcome 8 - Takes measures regarding health." has been observed to be taking part in two activities, "Outcome 4- Has adequate and balanced nutrition." in five activities and "Outcome 6- Uses the necessary tools and equipment for the daily life skills" in two activities. This situation makes us think that "Outcome 8 - Takes measures regarding health." is being emphasized among the outcomes related to food and nutrition discussed under the self-care skills title of PABFT (2018). There are 341 activities in the PABFT (2018) and 40 activities in the PEPAB (MEB, 2013b). Due to the low number of activities in the PEPAB (MEB, 2013b), it can be interpreted as that the content is limited and that therefore concepts related to food and nutrition are not included.

In line with the second sub-objective of the study, the learning processes of the activities, in which the outcomes and indicators (Outcomes 4, 6, and 8) related to food and nutrition in the activities in the PEPAB (MEB, 2013b) and the PABFT (2018), were examined. PEPAB (MEB, 2013b) could not be discussed in this sub-objective because the outcomes and the indicators related to food and nutrition were not included in the activities of the PEPAB (MEB, 2013b). When the learning processes of the 15 activities, which included the outcomes 4, 6, and 8 in PABFT (2018), it was seen that there was no food and nutritional content in the learning process in seven activities. All of these activities include the outcome 8, "It should not be forgotten that the most important conditions of a healthy life are adequate and balanced nutrition, enough rest/sleep and doing the necessary body movements. Informative activities should be held on common paediatric diseases, on the ways of protection from them and on treatment methods." (MEB, 2013). In this direction, it can be stated that some activities that contain the outcome 8 include the importance of adequate and balanced nutrition, as well as hygiene, sleep patterns, rest and physical activity.

When the learning process of the activities in the PABFT (2018) is analysed we can see that the learning process of eight activities had food and nutritional content. In the learning processes of these activities; it was determined that the importance of adequate and balanced nutrition, of the consumption of fruits and vegetables, of some animal foods, of paying attention to mealtimes and of the food plate, the benefits of foods and the harm of packaged foods, the place of some foods in our culture, nutrients that must be consumed for our organs to function properly, eating rules, examining the structure of various foods and culinary studies are included in general. In the study of Carraway-Stage et al. (2014), they stated that the nutrition education of teachers and administrators should consist of content should support cultural foods, the benefits of food and the ability to make healthy food choices, the amount of food we need to consume, food groups, food preparation, cleaning rules in food preparation and consumption process, healthy habits and lifestyle. It is seen that there is a parallelism between the views in the study and the learning processes of the activities with food and nutrition content in the PABFT (2018). In the preschool period, it is important for children to consume foods with protein value such as milk, yogurt and eggs for bone

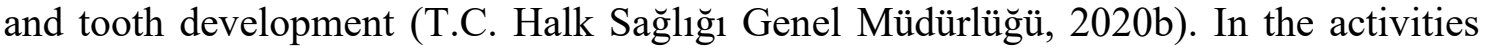
within the PABFT (2018), it is thought that emphasizing the benefit of yogurt and eggs and their freshness and making yogurt together will support children to consume foods by developing a positive attitude towards these foods. In a study, it was observed that some of the children participating in the study skip meals, do not consume vegetables 
and tend to ready-made food (Akar, 2006). In one of the results obtained in the study of Uzakgiden (2015) examining the nutritional perceptions of children, it was found that children expressed the number of meals as three, but they lacked information about snacks. Children need to consume five to six meals a day, and when the number of meals decreases, the amount of nutrients required per day cannot be fulfilled. In addition, when meals are served without skipping and considering that it is a behavior acquired in the early period (Nutritional Suggestions and Menu Programs for Preschool and School-Age Children, 2013; TÜBER, 2016), it is understood that it is important to mention the mealtimes in the activities. It is known that consuming various foods is necessary for a healthy diet. The Childhood Obesity Research Turkey was carried out with Primary School 2nd Grade Students. As a result of the study, the consumption frequency of recommended food groups in the Turkey Nutrition Guide was detected as low for the children and it was stated that correct information and training should be provided on this subject (COSI-TUR, 2017). In TÜBER (2016), the Turkey specific dietary pattern has been expressed in two ways and one is formed by "Healthy Food Plate". The Healthy Food Plate includes food groups in order to increase awareness about healthy life and make it easy to understand, and it is expected to choose 1 food from each food group at meals. Finding activities that emphasize the harm of packaged foods, encourage eating vegetables and include mealtimes and food plates in the activities within the PABFT (2018), make think that children will transform these behaviours into habits, understand the importance of healthy nutrition and that their knowledge and awareness about adequate and balanced nutrition will increase.

In line with the third sub-objective of the study, the status of the learning process of activities that do not represent the outcomes and indicators related to food and nutrition, in the PEPAB (MEB, 2013b) and the PABFT (2018) have been examined. It has been determined that concepts related to food and nutrition are not included in the learning process of the activities in the PEBAP (MEB, 2013b) in the meantime eighter learning processes related to food and nutrition in the PABFT (2018). In their work in (2016), Sönmez and Seyhan examined the MoNE 2013 Preschool Education Program in terms of the concept of health. As a result of the study, it was determined that the program emphasizes physical health. Physical health; includes physical condition, nutrition and hygiene issues. In this case, it can be said that the program emphasizes the importance of nutrition. The obtained result suggests that food and nutritional contents should be included in the PEPAB (MEB, 2013b) activities prepared in line with the program. In the PEP, one of the aims of Preschool Education is stated as "To ensure that children develop physical, mental and emotional development and gain good habits (MEB, 2013)". Considering the basic principles of preschool education, it is seen that one of the principles is "Preschool Education should support the child's motor, social and emotional, language and cognitive development, provide self-care skills and prepare him/her for primary school (MEB, 2013)". In light of the information given above; it is understood that in preschool education, it is necessary to make children acquire good habits and achieve self-care skills. However, it is observed that the content related to food and nutrition is lacking in the outcome, indicator and learning processes of the activities, which are presented with the PEP (MEB, 2013a) book and whose purpose is to guide the teacher. The preschool period has an important place in gaining nutritional habits, during this period, problems with nutrition negatively affect mental 
development and cause future health problems (obesity, chronic diseases, etc.) (TÜBER, 2016). To prevent obesity and diseases caused by obesity, one of the goals in the "Action Plan on Prevention of Childhood Obesity" is to encourage healthier environments in schools and pre-school. It is aimed to start the school meal program, to increase the consumption of healthy food in schools, to direct children to health institutions according to their weight, the inclusion of nutrition and physical activity programs from Preschool Education is stated as necessary (Türkiye Sağlıklı Beslenme ve Hareketli Hayat Program1, 2019). When we look at the PEPAB (MEB, 2013b), it is understood that it is incomplete in terms of the expressions stated in the Action Plan on Prevention of Childhood Obesity. Diab (2015) investigated the effect of the nutrition guide prepared for preschool teachers on the healthy growth of children. It was determined through the nutrition guide, that teachers' knowledge about nutrition increased and their activities improved, that malnutrition behaviours in children were prevented and this situation positively affected growth. In light of the research, the importance of the content offered in the resources that teachers use during the nutrition education, being guiding and rich in nutritional content becomes clear. In a study conducted with teachers about the difficulties and opportunities encountered in the nutrition education process, it was observed that teachers emphasized the difficulties related to the lack of appropriate curriculum, the cost of nutrition education, lack of sufficient knowledge, difficulties with food offered at home and school and lack of time in the classroom (Perera, Frei, Frei, Wong, \& Bobe, 2015). While creating their activities, teachers should notice the lack of food and nutrition in the resources provided to them and accordingly, they should prepare activities with food and nutritional content. For this, it can be stated that it is important for teachers to have information about food and nutrition issues and to receive training on this subject. Considering the studies and explanations about the pre-school period, which is important for achieving healthy eating habits; it is thought that the content of the activities presented in the PEPAB (MEB, 2013b), which is a guide for teachers in the process of preparing activities, should be reviewed in terms of outcomes related to food and nutrition in the field of self-care skills.

In the 15 activities included in the PABFT (2018), it was determined that the concepts of food and nutrition were included in the learning processes of these activities although the outcomes and indicators related to food and nutrition were not discussed. When the learning processes of the activities are investigated in terms of food and nutrition, the environment of food cultivation and its place in our culture are generally mentioned and benefits of foods and consuming the seasonal foods are emphasized by introducing them. Besides, foods are grouped according to their tastes and also it includes the culinary works. On the basis of nutrition education, it is stated that children should taste healthy foods and that the likelihood of consuming foods will increase when they are tasted. It is emphasized that taste activities in the classes can be created by predicting the appearance and smell of foods (Action for Healthy Kids, 2020). The Food and Agriculture Organization of the United Nations (FAO, 2005b) stated that children should be actively involved in the process by experiencing, observing, interpreting and making choices about Nutrition Education in the classroom. When the learning process of the activities that include the concepts of food and nutrition in the PABFT (2018) is examined, it can be said that there is a parallelism between the 
statements in those included in the learning processes of the activities and the expressions stated about the contents of activities in FAO (2005) and in Action for Healthy Kids. Studies on the preparation of Nutrition Education-related materials and situations encountered in the practice by both policymakers and researchers, highlight the importance of the subject. Lynch (2014) examined the Preschool Education Curriculum offered by the Ministry of Education in various states of Canada and the nutritional content of the auxiliary guides offered to implement the curriculum. In the states where there is an application guide with the study; it has been revealed that food preparation, the introduction of the Canada Food Guide, the importance of food selection and drama studies are included. In the USA, there is a Discover MyPlate nutrition training set carried out by the Ministry of Agriculture. In the preschool program of the set, healthy food choices, the variety of vegetables and fruits, observing how they grow, defining hunger and satiety status and the importance of physical activities for our health are included (USDA Food and Nutrition Service, 2020). In the study conducted by Her (2010) to develop a nutrition textbook for elementary school students, students stated that they wanted to get information on subjects such as cooking and healthy foods. In the book developed in this direction, five main titles such as traditional nutrition culture, cooking, eating habits, etc. are included (Her, 2010).

When the activities determined to be related to the concepts of food and nutrition in the PABFT (2018) are generally examined; it is seen that children are given the opportunity to cook and take part in kitchen activities, that the discovery of nutrients with sense organs is provided, that the place of some foods in our culture is explained, that children are actively involved in the process and gain through playing games and that the consumption of fruit and vegetables is encouraged in most of the activities. Nutrition education has aims such as supporting society and environment by gaining a healthy eating habit that children can maintain in their lives. In order to achieve the goals, it is necessary to ensure that children actively participate in nutrition education, to provide studies where they can apply what they have learned (cooking etc.) and to ensure that they understand the importance of nutrition for health (Food and Agriculture Organization of the United Nations, 2005b). Through the food tasting and classroom meal preparation activities, children are actively involved in the process and become more willing to consume healthy foods. When it is not known exactly how the food is cooked, distrust may occur in children and this may cause children to turn to convenience foods (The Nutrition Education Resource Guide for California Public Schools, 2017). In the Healthy Eating Guidelines (2004), it is stated that mealtimes and regular meals are important in gaining healthy eating habits, that implementing programs that encourage fruit and vegetables and spending time every day for nutrition in the program will positively affect healthy food preferences and that various opportunities should be created for tasting new foods. Although the duration of teachers' involvement in food and nutrition activities is outside the scope of this study, it is seen that other expressions emphasized as important in the Healthy Eating Guidelines take place in the activities in the PABFT (2018). In a study, it was found that the frequency of children consuming vegetables was low and that vegetables ranked last in food preferences (Kabacık \& Gül, 2016). For this reason, it is important to have applications that will encourage them to consume fruit and vegetables and to include them in the curriculum. In the study of Demiriz and Özgen (2019), it was found that the 
reason why children do not prefer fruit and vegetable consumption according to the opinions of the mothers and children is related to their taste or to the fact that they have never eaten it at all. It has been stated that children can actively participate in the food preparation process or consume foods they do not like with different presentations in school and home activities. In their study with children between 12 and 36 months of age, Dazeley and Houston-Price (2015) found that the inclusion of fruits and vegetables during games and their tactile recognition of these fruits and vegetables can lead them to be more willing to eat. And in another study, it was stated that early childhood is a critical period for interventions that will affect food preferences and that the recognition of foods will affect preferences. The study aiming to develop positive attitudes towards vegetables in children with play-based education revealed children's desire to taste and discover vegetables (Whiteley \& Matwiejczyk, 2015). Consistent with the results of the research and literature, the activities in the PABFT (2018), which include the content related to food and nutrition in the outcome, indicators and learning processes, are believed to make teachers aware of the healthy eating habits of children and will also guide how to plan activities related to food and nutrition.

\section{Result and Suggestions}

At the end of the study carried out in order to evaluate the activities in the PEPAB (MEB, 2013b) and PABFT (2018), in terms of food and nutrition outcomes and learning processes; we can notice that in the PEPAB (MEB, 2013b) the activities determined under the heading of self-care skills outcome 4, 6 and 8 were not included. On the other hand, when examining the inclusion of concepts related to food and nutrition in the learning processes of the PEPAB (MEB, 2013b) activities, no concept related to food and nutrition has been found. In the activities included in the PABFT (2018), we can notice that the outcomes 4, 6 and 8' determined under the title of selfcare skills of the program book, are taking place in 15 activities, however, when the learning processes of these activities were examined, it was seen that only eight activities had concepts related to food and nutrition in the learning process. In addition, in the activities included in the PABFT (2018), it was found that food and nutritionrelated content took place in the learning process of 15 activities although the outcomes 4, 6 and 8 are not included. At the end of the study, it is considered as important that;

1. In other studies; more in-depth analysis can be done with content analysis; data can be collected more in-depth through observations and interviews by using the data diversification method in different studies,

2. The PEPAB (MEB, 2013b) can be reviewed in a way to include the outcomes and activities related to food and nutrition by re-examining the scope of activities,

3. In-service trainings can be carried out for teachers to realize the importance of the subject and to enrich their practices in terms of nutrition education and activities

4. Nutrition education programs and activities can be created along with an interdisciplinary approach by using the Turkey Dietary Guidelines (TDG) leading the way in order to form healthy food habits and the Turkey Nutrition and Health Research (TNHR) mentioning health problems caused by nutrition. 


\section{Statement of Responsibility}

Gülşah İnalc1k; methodology, resources, data collection, validation, analysis, writing - original draft, writing - review \& editing, visualization. Duriye Esra Angin; design of the project, conceptualization, methodology, resources, validation, writing original draft, writing - review \& editing, supervision. 


\section{References}

Ackerhelden. (2020). Ackerhelden Machen Schule. Obtained on 29.11.2020 from https://www.ackerhelden.de/ams-english/

Action for Healthy Kids. (2020). Obtained on 01.06 .2020 from https://www.actionforhealthykids.org/activity/host-a-taste-test/\#.

Akar, A. S. (2006). Özel ve resmi okul öncesi eğitim kurumlarına devam eden 4-6 yaş grubu çocuklarının beslenme alışkanlıklarının karşılaştırılması (Yayınlanmamış yüksek lisans tezi). Gazi Üniversitesi, Ankara.

Aktaç, Ş. (2016). Okul öncesi çă̆ çocuklar için aile katılımlı beslenme eğitim modelinin geliştirilmesi ve çocukların beslenme bilgi ve davranışlarl üzerine etkisinin değerlendirilmesi (Yayınlanmamış doktora tezi). Başkent Üniversitesi, Ankara.

Aktaş, N. (2011). İlköğretim 1-3. sınıf hayat bilgisi ders programının besin ve beslenme ile ilgili kazanım ve etkinlikler açısından incelenmesi. Selçuk Üniversitesi Sosyal Bilimler Enstitüsü Dergisi, 26, 23-31.

Aktaş, N., \& Angın, D. E. (2015). Erken Çocukluk Döneminde Beslenme Eğitimi. 3. Uluslararası Helal ve Sağlıklı Gıda Kongresi. "Helal ve Sağlıklı Beslenmede Farkındalık ve Sürdürülebilirlik” Kongresi içinde (s. 171-172). Konya: Necmettin Erbakan Üniversitesi.

Al-Hussein, R. Y., \& Kano, A. E. K. (2018). Relationship between family life-style and nutritional status among kindergarten children in Nineveh Governorate. Mosul Journal of Nursing, 6(2), 62-71.

Alay, F. (2019). Okul çă̆l çocuklarına verilen beslenme ĕgitimi programının beslenme alışkanlıkları besin tüketim slklıkları ve beslenme bilgi düzeyi üzerine etkisinin değerlendirilmesi (Yayınlanmamış yüksek lisans tezi). Aydın Adnan Menderes Üniversitesi, Aydın.

Angın, D. E., Aktaş, N., \& Cebirbay, M. A. (2015). A Nutrition guide for early childhood active stakeholders. The Journal of International Education Science (Uluslararası Eğitim Bilimleri Dergisi), 4, 419-426.

Aydın, O., Madi, B., Alpanda, S., \& Sazc1, A. (2012). MEB okul öncesi eğitim programının nörogelişimsel açıdan değerlendirilmesi. M. ̈. Atatürk Eğitim Fakültesi Eğitim Bilimleri Dergisi, 36, 69-93.

Aytekin, K. Ö. (2013). Aile içi etkileşim ve masallarla desteklenmiş beslenme eğitiminin 5-6 yaş çocukların beslenme biçimlerine etkisinin incelenmesi (Yayınlanmamış doktora tezi). Selçuk Üniversitesi, Konya.

Başkale, H. (2010). Okul öncesi çocuklara verilen beslenme eğitiminin çocukların beslenme bilgisine, davranışlarına ve antropometrik ölçümlerine etkisi (Yayınlanmamış doktora tezi). Dokuz Eylül Üniversitesi, İzmir.

Başkale, H. (2016). Nitel araştırmalarda geçerlik, güvenirlik ve örneklem büyüklüğünün belirlenmesi. Dokuz Eylül Üniversitesi Hemşirelik Fakültesi Elektronik Dergisi, 9(1), 23-28.

Benton, D. (2008). The influence of children's diet on their cognition and behaviour. European Journal of Nutrition, 47(3), 25-37. 
Food and Agriculture Organization of the United Nations [FAO]. (2005a). Nutrition education in primary schools. Obtained on 15.05 .2020 from http://www.fao.org/3/a-a0333e.pdf

Food and Agriculture Organization of the United Nations [FAO]. (2005b). Nutrition education in primary schools. Obtained on 15.05 .2020 from http://www.fao.org/3/a0333e/a0333e01.pdf

Carraway-Stage, V., Henson, S. R., Dipper, A., Spangler, H., Ash, S. L., \& Goodell, S. (2014). Understanding the state of Nutrition Education in the Head Start classroom: A qualitative approach. American Journal of Health Education, 45(1), 52-62. http://dx.doi.org/10.1080/19325037.2013.853000

Curriculum Development Council. (2017). Kindergarten education curriculum guide. Obtained on 04.06.2020 from https://www.edb.gov.hk/attachment/en/curriculumdevelopment/major-level-of-edu/preprimary/ENG_KGECG_2017.pdf.

Curriculum Pentru Educatia Timpurie Romania. (2019). Obtained on 29.11.2020 from https://www.edu.ro/sites/default/files/Curriculum\%20ET_2019_aug.pdf

Dazeley, P., \& Houston-Price, C. (2015). Exposure to foods' non-taste sensory properties. A nursery intervention to increase children's willingness to try fruit and vegetables. Appetite, 84, 1-6. http://dx.doi.org/10.1016/j.appet.2014.08.040.

de Vlieger, N., Riley, N., Miller, A., Collins, C. E., \& Bucher, T. (2018). Nutrition Education in the Australian New South Wales primary school curriculum: An exploration of time allocation, translation and attitudes in a sample of teachers. Health Promotion Journal of Australia, 30(1), 94-101. http://dx.doi.org/10.1002/hpja.188

Demiriz, S., \& Özgen, L. (2019). Çocukların sebze ve meyve tüketim durumu: Anne ve çocuk görüşleri. Gazi Üniversitesi Gazi Eğitim Fakültesi Dergisi, 39(2), 681-701.

Diab, S. S. E. M. (2015). Effect of nutritional guideline for kindergarten teachers on healthy physical growth of preschool children. IOSR Journal of Research \& Method in Education, 5(4), 17-25. http://dx.doi.org/10.9790/7388-05411725

Eğitim Bilişim Ağı (EBA). (2020a). Etkinlik Havuzu Neden Oluşturuldu?. 05.04.2020 tarihinde http://okuloncesi.eba.gov.tr/Haber/Detay/2 adresinden alınmıştır.

Eğitim Bilişim Ağı (EBA). (2020b). Etkinlik Kitabının Özellikleri Nelerdir?. 05.04.2020 tarihinde http://okuloncesi.eba.gov.tr/Haber/Detay/3\# adresinden alınmıştır.

Franciscato, S. J., Janson, G., Machado, R., Lauris, J. R. P., Andrade, S. M. J., \& Fisberg, M. (2019). Impact of the Nutrition Education program Nutriamigos ${ }^{\circledR}$ on levels of awareness on healthy eating habits in school-aged children. J Hum Growth Dev, 29(3), 390-402. https://doi.org/10.7322/jhgd.v29.9538

Healthy Eating Guidelines. (2004). Obtained on 15.05 .2020 from https://www.education.sa.gov.au/sites/default/files/healthy_eating_guidelines.pdf?v $=1465356381$.

Her, E. (2010). Development of practical dietary education textbook and teaching manual in elementary school students. Korean Journal of Community Nutrition, 15(5), 636-647. 
Hu, C., Ye, D., Li, Y., Huang, Y., Li, L., Gao, Y., \& Wang, S. (2008). Evaluation of a kindergarten-based nutrition education intervention for pre-school children in China. Public Health Nutrition, 13(2), 253-260. http://dx.doi.org/10.1017/S1368980009990814

Ilaş, S. (2015). Nutritional education in kindergarten - An analysis of the Romanian preschool curriculum. Revista de Științe ale Educației, 31(1), 62-72.

Kabacık, S. Ç., \& Gül, E. B. (2016). Anasınıfına devam eden çocukların sebzelere ilişkin tepkilerinin incelenmesi: Proje yaklaşımı örneği. Kastamonu Education Journal, 24(5), 2323-2334.

Kandır, A., \& Türkoğlu, D. (2015). MEB 2013 Okul Öncesi Eğitim Programının müzikal becerilerin gelişimi yönünden değerlendirilmesi. Hacettepe University Faculty of Health Sciences Journal, 2, 339-350.

Karaoğlu, N., \& Samur, G. E. (2017). Anne Çocuk Beslenmesi. Ankara: Pegem.

Kartal, H., \& Güner, F. (2017). Okul öncesi eğitim programı etkinlik kitabındaki etkinliklerin ses bilgisi farkındalığı açısından incelenmesi. Journal of Mother Tongue Education, 5(1), 14-30.

Kerkez, F. İ. (2018). 4-5 yaş çocukların sağlıklı besin bilgisi ve tercihinin incelenmesi. E-Journal of International Educational Researches, 9(3), 47-59. http://dx.doi.org/10.19160/ijer.405535

Kobak, C., \& Pek, H. (2015). Okul öncesi dönemde (3-6 yaş) ana çocuk sağlığı ve anaokulundaki çocukların beslenme özelliklerinin karşılaştırılması. Hacettepe University Journal of Education, 30(2), 42-55.

Kocalar, E. (2019). 2013 Okul Öncesi Ĕ̆itim Programının karakter eğitimi açısından değerlendirilmesi (Yüksek lisans tezi). Gaziantep Üniversitesi, Gaziantep.

Köroğlu, S. (2009). Okul öncesi dönem 4-6 yaş arası çocuklarda aileden kaynaklanan beslenme bozukluklarının incelenmesi (Yayınlanmamış yüksek lisans tezi). Selçuk Üniversitesi, Konya.

Küçükkömürler, S. (2015). Okul öncesi dönemde çocuğun beslenmesi (1-6 yaş). Anne ve çocuk beslenmesi içinde (ss.185 -191). Ankara: Pegem Yayıncılık.

Liu, H., Xu, X., Liu, D., Rao, Y., Reis, C., Sharma, M., ... \& Zhao, Y. (2018). Nutritionrelated knowledge, attitudes, and practices (KAP) among kindergarten teachers in Chongqing, China: A cross-sectional survey. International Journal of Environmental Research and Public Health, 15(4), 615.

Lynch, M. (2014). Developing long-term healthy eating behaviours in Canadian Kindergarten Curricula. Revue PhénepS/Phenex Journal, 6(2), 1-28.

Marotz, L. R. (2012). Health, Safety, and Nutrition for the Young Child. Wadsworth, Cengage Learning. Obtained on 15.04 .2020 from https://college.cengage.com/early_childhood_education/course360/health_safety_a nd_nutrition_1111942250/ebook/marotz_1111298378_ch01.pdf

Matvienko, O. (2007). Impact of a Nutrition Education Curriculum on Snack Choices of Children Ages Six and Seven Years. Journal of Nutrition Education and Behaviour, 39(5), 281-285. http://dx.doi.org/10.1016/j.jneb.2007.01.004 
Merdol, T. K. (2008). Okul Öncesi Dönem Çocuklarının Beslenmesi. 15.04.2020 tarihinde https://sbu.saglik.gov.tr/Ekutuphane/kitaplar/A\%2010.pdf adresinden edinilmiştir.

Milli Eğitim Bakanlığ́ [MEB]. (2013a). Okul Öncesi Eğitim Programı. 20.03.2020 tarihinde https://tegm.meb.gov.tr/dosya/okuloncesi/ooproram.pdf adresinden edinilmiştir.

Milli Eğitim Bakanlığı [MEB]. (2013b). Okul Öncesi Eğitim Programı Etkinlik Kitabı. 20.03.2020 tarihinde http://tegm.meb.gov.tr/dosya/okuloncesi/okuloncesietkinlikkitabi.pdf adresinden edinilmiştir.

Milli Eğitim Bakanlığı Dijital Eğitim Platformu Eğitim Bilişim Ağı (EBA) Öğretmenler için Okul Öncesi Etkinlik Kitabı. (2018). 20.03.2020 tarihinde http://www.eba.gov.tr adresinden edinilmiştir.

Musaoğlu, E. B. (2012). MEB 36-72 aylık çocuklar için okul öncesi eğitim programının (2006) çocuk hakları açısından incelenmesi (Yayınlanmamış yüksek lisans tezi). Ankara Üniversitesi, Ankara.

Nguyen, K. A., de Villiers, A., Fourie, J. M., Bourne, L. T., \& Hendricks, M. K. (2013). The Feasibility of Implementing Food-based Dietary Guidelines in the South African Primary-School Curriculum. Public Health Nutrition, 18(1), 167-175. http://dx.doi.org/10.1017/S1368980013003194

Obalı, H. (2009). Okulöncesi ĕgitimi almakta olan altı yaş grubu çocuklarına verilen proje yaklaşımıyla beslenme eğitimin beslenme bilgi düzeyine etkisi (Yüksek lisans tezi). Selçuk Üniversitesi, Konya.

Ocak, I., Duban, N., \& Yağıcı, G. (2016). İlkokul öğrencilerinin kişisel bakım, temizlik ve beslenme ile ilgili görüşleri. Atatürk Üniversitesi Sosyal Bilimler Enstitüsü Dergisi, 20(4), 1249-1263.

Oğuz, Ş. (2011). Konya il merkezinde okulöncesi ĕgitim kurumlarına devam etmekte olan 60-72 aylık çocukların beslenme alışkanlıkları (Yayınlanmamış yüksek lisans tezi). Selçuk Üniversitesi, Konya.

"Okul Öncesi ve Okul Çağı Çocuklara Yönelik Beslenme Önerileri ve Menü Programları” Türkiye Halk Sağlı̆̆ı Kurumu Yayın No: 915, Ankara 2013.

Özcan, B. A. (2019). Doğrudan veya dolaylı verilen beslenme eğitiminin çocukların beslenme durumlarına etkisi (Yayınlanmamış doktora tezi). Başkent Üniversitesi, Ankara.

Perera, T., Frei, S., Frei, B., Wong, S. S., \& Bobe, G. (2015). Improving nutrition education in U.S. elementary schools: Challenges and opportunities. Journal of Education and Practice, 6(30), 41-50.

Proclamation of the Ministry of Education and Human Resources Development. (2007). $\begin{array}{llll}\text { Obtained on } & 05.06 .2020 & \text { from }\end{array}$ http://ncm.gu.se/media/kursplaner/andralander/koreaforskola.pdf.

Skolverket. (2020). Obtained on 24.05.2020 from https://www.skolverket.se/undervisning/forskolan/laroplan-for-forskolan/laroplanlpfo-18-for- 
forskolan?url=1530314731/compulsorycw/jsp/curriculum.htm?tos=fsk\&sv.url=12 189c87ae1623366ff371f3f.

Sönmez, S., \& Seyhan, G. B. (2016). Meb 2013 Okul Öncesi Eğitim Programının sağlık kavramı açısından incelenmesi. Turkish Online Journal of Qualitative Inquiry (TOJQI), 7(1), 146-174.

Şenturan, B. (2017). Okul öncesi dönem çocuklarına matematik eğitimi içerikli beslenme eğitimi verilmesinin yeterli ve dengeli beslenme bilgisine etkisi (Yüksek lisans tezi). Necmettin Erbakan Üniversitesi, Konya.

Tayar, M., Korkmaz, N. M., \& Özkeleş, E. (2017). Beslenme ve sağl1k. Beslenme ilkeleri içinde (ss. 1-21). Bursa: Dora.

T.C. Halk Sağlığı Genel Müdürlüğü. (2020a). 26.05.2020 tarihinde https://hsgm.saglik.gov.tr/tr/okul-sagligi/liste/okul-beslenme-ve-fiziksel-aktiviteegitim-materyalleri.html adresinden edinilmişstir.

T.C. Halk Sağlığı Genel Müdürlügü. (2020b). 26.05.2020 tarihinde https://hsgm.saglik.gov.tr/tr/beslenme/okul-oncesi-saglikli-beslenme.html adresinden edinilmiştir.

T.C. Sağlık Bakanlığı (2014). Türkiye Beslenme ve Sağlık Araştırması 2010: Beslenme durumu ve alışkanlıklarının değerlendirilmesi sonuç raporu, Sağlık Araştırmaları Genel Müdürlüğü, Sağlık Bakanlığı, https://hsgm.saglik.gov.tr/depo/birimler/saglikli-beslenme-hareketli-hayatdb/Yayinlar/kitaplar/diger-kitaplar/TBSA-Beslenme-Yayini.pdf. 20.04.2020

Tepe, E. (2010). Okul öncesi kurumlarındaki çocukların ailelerinin ve öğretmenlerinin çocuk beslenmesine ilişkin görüşleri (Yayınlanmamış yüksek lisans tezi). Afyon Kocatepe Üniversitesi, Afyonkarahisar.

The Nutrition Education Resource Guide for California Public Schools, Kindergarten Through Grade Twelve. (2017). [e-book version] https://www.cde.ca.gov/ls/nu/he/documents/nergcomplete.pdf

Tuğluk, M. N., \& Özkan, B. (2019). MEB 2013 Okul Öncesi Eğitim Programının 21. yüzyıl becerileri açısından analizi. Journal of Primary Education, 1(4), 29-38.

“Türkiye Beslenme Rehberi [TÜBER] 2015”, “T.C. Sağlık Bakanlığı Yayın No: 1031, Ankara 2016."

“Türkiye Çocukluk Çağı (İlkokul 2. Sınıf Öğrencileri) Şişmanlık Araştırması - COSITUR 2016" Sağlık Bakanlığı, Halk Sağlığ1 Genel Müdürlüğü, Milli Eğitim Bakanlığı, Dünya Sağlık Örgütü Avrupa Bölge Ofisi, Sağlık Bakanlığı Yayın No: 1080, Ankara 2017

"Türkiye Sağlıklı Beslenme ve Hareketli Hayat Programı" Sağlık Bakanlı̆̆ı, Halk Sağlı̆̆ı Genel Müdürlüğü, Sağlık Bakanlığı Yayın No: 773, Ankara 2019.

USDA Food and Nutrition Service. (2020). Obtained on 01.06 .2020 from https://www.fns.usda.gov/tn/discover-myplate-nutrition-educationkindergarten\#anchor1.

Uzakgiden, D. (2015). Okul öncesi eğitime devam eden çocukların beslenme algılarının incelenmesi (Yayınlanmamış yüksek lisans tezi). Ege Üniversitesi, İzmir. 
Ünver, Y. (2004). Beş-altı yaş okul öncesi dönemi çocukları için geliştirilecek, besin gruplarına yönelik beslenme eğitimi programlarının, çocukların beslenme bilgisi ve davranışlarına etkisi (Yayımlanmamış yüksek lisans tezi). Selçuk Üniversitesi, Konya.

Yalçın, F. A., \& Yalçın, M. (2018). Okul öncesi öğretmenlerin okul öncesi eğitimin sorunlarıyla ilgili görüşleri: Ağrı ili örneği. Primary Education Online, 17(1), 367383. http://dx.doi.org/10.17051/ilkonline.2018.413784

Yıldırım, A., \& Şimşek, H. (2016). Sosyal bilimlerde nitel araştırma yöntemleri. Ankara: Seçkin.

Whiteley, C., \& Matwiejczyk, L. (2015). Preschool program improves young children's food literacy and attitudes to vegetables. Journal of Nutrition Education and Behaviour, 47(4), 397-98. http://dx.doi.org/10.1016/j.jneb.2015.04.002.

World Health Organization [WHO]. (2020). Malnutrition. Obtained on 28.11.2020 from https://www.who.int/news-room/fact-sheets/detail/malnutrition 